\title{
Hubungan Intensitas Penggunaan Smartphone dengan Disiplin Belajar Siswa Kelas X SMAN 2 Pariaman
}

\author{
Hanifa Septiani ${ }^{1}$, Ike Sylvia ${ }^{2}$
}

\author{
${ }^{1,2}$ Universitas Negeri Padang \\ Email: hanifaseptiani@yahoo.co.id, $\underline{\text { ikesylvia@fis.unp.ac.id }}$
}

\begin{abstract}
Abstrak
Penelitian ini bertujuan untuk mengetahui hubungan intensitas penggunaan Smartphone dengan disiplin belajar siswa kelas X SMA N 2 Pariaman. Maka jenis penelitian ini adalah penelitian ex-post facto yang bersifat korelasional. Teknik pengambilan sampel yang digunakan dalam penelitian ini proporsional random sampling, Jumlah siswa kelas X SMA N 2 Pariaman berjumlah 354. Dalam penelitian kali ini digunakan tingkat kesalahan sebesar $10 \%$ sehingga sampel yang diperlukan adalah 78 orang. Penelitian ini penggunakan dua macam variabel yaitu: 1) variabel bebas: intensitas penggunaan smartphone (X) 2) variabel terikat: disiplin belajar $(\mathrm{Y})$. Pengumpulan data untuk variabel intensitas penggunaan smartphone dan disiplin belajar menggunakan metode angket dengan skala Likert. Keabsahan data diperoleh melalui uji validitas dan reliabelitas. Teknik analisis data yang digunakan adalah analisis deskriptif untuk melihat (mean,mediam,modus, dan standar deviasi). Teknik analisis data yang digunakan antara lain kategoris persentase, uji normalitas, analisis untuk uji hipotesis menggunakan rumus korelasi product moment.
\end{abstract}

Kata Kunci: Intensitas, Smartphone, Disiplin

\section{Abstract}

The study aims to know the intensity of the use of smartphones with the discipline of learning students of grade $X$ SMA N 2 Pariaman. Thus this type of research is a correlational, ex-post facto research. The sampling techniques used in this study are proportional random sampling, total grade X students SMA N 2 Pariaman amounted to 354. In the study this time used error rate of $10 \%$ so the required sample is 78 people. This research uses two kinds of variables namely: 1) Free variables: Smartphone usage intensity $(X)$ 2) Bound variables: Learning Discipline (Y). Data collection for the intensity variable of smartphone use and learning discipline using poll method with Likert scale. The validity of the data is obtained through validity and reliability tests. The data analysis techniques used are descriptive analysis for viewing (mean, Mediam, mode, and standard deviation). The data analysis techniques used are categorical percentages, test normality, analysis for hypothesized testing using a correlation formula of product moment.

Keywords: Intensity, Smartphone, discipline

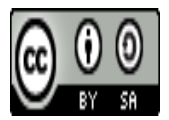

Received: August 5, 2019 Revised: August 8, 2019 Available Online: September 30, 2019

Jurnal Sikola: Jurnal Kajian Pendidikan dan Pembelajaran Vol. 1, No. 1, Th. 2019

ISSN. 2715-1735

Copyright@2019, by Author 


\section{Pendahuluan}

Disiplin merupakan masalah yang sering dihadapi oleh sekolah-sekolah di indonesia. Sekolah adalah lembaga pendidikan mempunyai peraturan tertentu yang dituangkan dalam bentuk aturan sekolah yang disebut dengan tata tertib, Tata tertib sekolah akan berjalan dengan baik jika sikap disiplin terhadap tata tertib atau peraturan. (Sylvia, 2012)

Pendidikan adalah salah satu cara membentuk SDM yang bermutu demi ketercapaian tujuan dalam pembangunan nasional. Dalam kegiatan pendidikan terjadi proses interaksi belajar-mengajar demi mendapatkan pengetahuan, keterampilan, nilai dan sikap sehingga menjadikan individu dapat berfikir lebih sistematis, rasional dan kritis (Rian Ayu Anggreani, 2015). Menurut (Imron, 2011) Disiplin adalah kondisi dimana berada dalam keadaan tertib dan teratur, serta tidak ada suatu masalah pelanggaran baik yang terjadi. Disiplin belajar adalah satu sikap atau perilaku yang harus dimiliki oleh siswa didalam proses pembelajaran (Muhammad Khafid, 2017). Didalam belajar yang akan diharapkan hasil belajar dan prestasi belajar siswa, akan tetapi untuk memperoleh hasil belajar yang baik tidak akan terwujud jika tidak adanya tertanam disiplin diri pada setiap siswa. Untuk memicu hasil belajar siswa yang baik, siswa tidak lagi dipaksakan untuk mengerjakan tugas, tapi mereka harus didorong untuk membangkitkan disiplin didalam diri individu agar mereka bisa belajar. Disiplin diri yaitu kesadaran diri akan tugas dan tanggung jawab serta kemampuan seseorang untuk patuh dan taat terhadap peraturan yang berlaku, jadi disiplin didalam diri sangat penting sebagai upaya membentuk sikap dan kepribadian siswa agar dapat bertanggung jawab dalam menerima tugas yang diberikan pendidik (Nurul Amalia, 2016). Indikator disiplin menurut (Yosi Tri Agustin, 2017) yaitu : mengatur waktu belajar di rumah, ketertiban diri saat belajar di kelas, memperhatikan dan mendengarkan penjelsan guru didepan kelas, serta menjalankan praktek dan keterampilan latihan.

Proses belajar mengajar, disiplin dapat menjadi alat yang bersifat preventif untuk mencegah hal-hal yang dapat mengganggu dan menghambat proses belajar. Proses belajar yang baik merupakan proses belajar yang bisa memudahkan siswa dalam memahami materi pelajaran yang diajarkan kepada peserta didik disekolah (Zainidar Aslianda, 2017). Untuk memperoleh prestasi belajar yang baik tidaklah mudah, banyak faktor yang mempengaruhiya diantaranya yaitu faktor internal (dari dalam individu siswa) dan faktor eksternal (dari luar individu siswa). Faktor siswa memegang peranan penting dalam mencapai prestasi belajar yang baik, karena siswa yang melakukan kegiatan belajar perlu memiliki kedisiplinan yang baik (Arisana, 2012).

Berdasarkan observasi awal yang penulis lakukan disekolah tepatnya di SMA Negeri 2 Pariaman, bahwa terdapat, masih rendahnya disiplin belajar siswa, hal ini berdasarkan analisis ciri- ciri siswa yang memiliki disiplin belajar menurut (Sulistiyowati, 2001), yaitu: Pertama, Mengarahkan energi untuk belajar secara kontinu. Bila sudah tiba waktunya untuk belajar kemudian diajak bermain oleh teman, maka siswa harus dapat menolak ajakan temannya secara halus agar tidak tersinggung. faktanya yang penulis amati di kelas X SMA Negeri 2 Pariaman, ketika jam pelajaran berlangsung masih banyak siswa yang bermain - main dalam kelas, ada yang mengganggu temannya sehingga sering mengalami kegaduhan didalam kelas.

Kedua, Melakukan belajar dengan sungguh-sungguh dan tidak membiarkan terbuang. Bila seorang siswa mempunyai jadwal kegiatan belajar, ia harus menepati jadwal yang telah dibuatnya.. faktanya berdasarkan pengamatan penulis saat mengajar di kelas X IPS banyak siswa yang tidak disiplin dalam menepati jadwal pelajaran atau masih ada siswa yang terlambat masuk kelas disaat bel masuk ke jam berikutnya sudah mulai, banyak diantara siswa menundanunda untuk masuk kelas dengan beralasan belum sarapan atau pas jam istirahat masih banyak yang belum makan, dan juga terjadi pada saat bel pergantian guru dan pelajaran berikutnya, banyak siswa yang keluar kelas dengan alasan mau membeli cemilan atau mau ke toilet atau hanya sekedar berdiri diluar kelas sampai guru berikutnya datang, yang seharusnya siswa harus menunggu didalam kelas sampai guru berikutnya hadir. Ada pula disaat pergantian jam merupakan kesempatan bagi siswa untuk bermain Smartphone, diantaranya ada yang main games, ber-media sosial atau menghidupkan musik.

Jurnal Sikola: Jurnal Kajian Pendidikan dan Pembelajaran Vol. 1, No. 1, Th. 2019

ISSN. 2715-1735

Copyright@2019, by Author 


\section{Hanifa Septiani, Ike Sylvia

Ketiga, Patuh terhadap aturan yang diberikan guru di dalam kelas. dalam proses belajar mengajar diperlukannya rambu-rambu peraturan yang dibuat oleh guru pelajaran agar disaat pelajaran berlangsung guru dapat mengendalikan, tetapi faktanya berdasarkan pengamatan penulis satu minggu masa observasi PLK di kelas X SMA Negeri 2 Pariaman, dengan adanya rambu - rambu yang diberikan oleh guru yang mengajar dikelas tidak banyak yang mematuhinya hanya beberapa orang siswa yang mematuhinya, seperti halnya dalam mengumpulkan tugas hanya beberapa siswa yang mengumpulkan tugas sedangkan yang lain banyak beralasan. ada juga siswa yang sibuk memainkan Smartphone, biasanya siswa tersebut cattingan dengan temannya, atau hanya sekedar mengecek dari media sosial yang mereka punya seperti (Whatshap, Facebook atau Instagram dan lainnya) dan tak jarang Smartphone yang dipunya juga dipakai buat bermain Games disaat jam pelajaran berlangsung sehingga siswa tidak berkonsentrasi lagi dengan pelajaran, tak jarang guru sering mengingatkan diawal pelajaran agar tidak bermain Smartphone ketika guru menerangkan, tetapi disaat kelas mulai tak kondusif kembali siswa bermain Smartphone, ada juga yang bila ketahuan Smartphone siswa tersebut ditangkap oleh guru pelajaran dan nanti akan dikembalikan lagi disaat pelajaran tersebut telah selesai tanpa perjanjian yg mengikat.

Keempat, Patuh dan taat terhadap tata tertib belajar di sekolah. sebagai seorang siswa patuh dan taat merupakan sebuah kewajiban terhadap berbagai tata tertib sekolah agar terlaksananya pembelajaran yang kondusif, tetapi faktanya berdasarkan pengamatan penulis selama proses praktek lapangan kependidikkan (PLK) pelanggaran yang dilakukan siswa tidak mencerminkan akan patuh dan taat pada tata terti sekolah misalnya, terlambat masuk sekolah pemakaian seragam yang kurang rapi Perilaku kedisiplinan di luar kelas di lingkungan sekolah yang peneliti amati, banyak siswa yang masih duduk-duduk dikantin disaat bel pelajaran sudah mulai, kemudian ada juga siswa yang ketahuan merokok diam - diam di dalam kantin serta yang paling menonjol yang peneliti amati dari perilaku siswa ada sekelompok siswa yang berada disamping kantin sedang menggunakan Smartphone, setelah ditanya ternyata mereka bermain game (mobile legend online) disaat jam pelajaran sudah mulai. Hal ini dipengaruhi oleh faktor kedisiplinan belajar siswa yang cenderung masih rendah dan dapat dilihat dari seringnya siswa menggunakan Smartphone atau bermain Mobile Legend atau lainnya banyak yang menggunakannya untuk membuka media sosial lainnya pada saat jam pelajaran berlangsung.

Kelima, Menunjukkan sikap antusias dalam belajar dan Keenam, Mengikuti kegiatan pembelajaran di kelas dengan gairah dan partisipatif. Siswa dapat menumbuhkan semangat belajar baik di sekolah maupun di rumah. Faktanya berdasarkan pengamatan penulis selama melaksanakan Praktek Lapangan Kependidikkan (PLK) hanya sedikit yang menunjukan sikap antusias dalam pelajaran tak jarang dalam diskusi yang sering tampil hanya itu saja siswanya, sedangkan siswa yang lain sibuk dengan yang lain dan tak jarang meribut selain itu juga ada yang suka tidur didalam kelas.

Ketujuh, Menyelesaikan tugas-tugas yang diberikan guru dengan baik. faktanya berdasarkan pengamatan penulis selama melaksanakan Praktek Lapangan kependidikkan (PLK) siswa tidak bisa menumbukan disiplin diri terlihat saat ada tugas yang seharusnya dibuat dirumah, tetapi banyak dari siswa yang tidak membuat tugas rumah, dan ketika ditagih oleh gurunya banyak dari mereka yang belum selesai bahkan beralasan tidak ingat kalau ada tugas rumah.

Kedelapan, Tidak melakukan hal-hal yang dilarang oleh guru. Bila seorang siswa telah melanggar hal-hal yang dilarang tentunya dalam peroses pembelajaran tidak akan berlangsung secara kondusif, seperti meribut, bermain Smartphone, menggangu teman, tidak mengumpulkan tugas, keluar masuk kelas dan lain-lain.

Dari uraian di atas jelaslah bahwa disiplin dalam belajar hendaknya dimiliki oleh setiap siswa yang akhirnya nanti bisa jadi kebiasaan, maka akan terbentuk etos belajar yang baik. Belajar bukan lagi sebagai beban melainkan sudah dianggap sebagai kebutuhan hidupnya. Disiplin yang sebenarnya mendorong anak untuk bekerja sama, memilih sikap yang tepat dan untuk menyambut peluang untuk memberikan konstribusi pada kelas, teman sebaya, dan keluarga 


\section{Hanifa Septiani, Ike Sylvia Hubungan Intensitas Penggunaan Smartphone dengan Disiplin Belajar Siswa Kelas X SMAN 2 Pariaman}

mereka (Cheryl, 2005). Namun berdasarkan analisis permasalahan kedisiplinan diatas banyak hal yang mempengaruhi kedisiplinan siswa dalam belajar, dan dari sekian banyak permasalahan yang muncul ada yang paling menonjol, dan membuat penulis tertarik untuk membahas permasalahan tersebut.

Berdasarkan hasil menyebarkan angket yang penulis lakukan, dikelas X IPS 3 di SMA 2 Pariaman, dapat diketahui dari 31 siswa yang hadir pada saat itu dari jumlah siswa 36 seluruhnya mengaku sudah menggunakan Smartphone, intensitas penggunaan Smartphone dari masing-masing siswa beragam, dari penggunaan Smartphone $\leq 1 \mathrm{jam}$ sampai $\geq 6$ jam/hari.

Berikut dibawah ini, adalah hasil data yang peneliti dapatkan dalam penyebaran Angket sementara, yaitu:

Tabel 1. Intensitas Pengunaan Smartphone

\begin{tabular}{|c|c|c|c|}
\hline Item Pertanyaan & Sering & $\begin{array}{l}\text { Kadang - } \\
\text { Kadang }\end{array}$ & $\begin{array}{l}\text { Tidak } \\
\text { Sering }\end{array}$ \\
\hline \multicolumn{4}{|l|}{ Video } \\
\hline Menonton video & 5 orang & 22 orang & 4 orang \\
\hline Mendownload (mengunduh) video & 8 orang & 17 orang & 6 orang \\
\hline Video call & 12 orang & 14 orang & 5 orang \\
\hline \multicolumn{4}{|l|}{ Media sosial } \\
\hline Mengirimi pesan & 23 orang & 6 orang & 2 orang \\
\hline Menerima pesan & 21 orang & 8 orang & 2 orang \\
\hline Menggungah foto dimedia sosial & 15 orang & 12 orang & 4 orang \\
\hline \multicolumn{4}{|l|}{ Musik/ lagu } \\
\hline Mendownload musik & 13 orang & 17 orang & 1 orang \\
\hline Mendengarkan musik & 21 orang & 8 orang & 2 orang \\
\hline \multicolumn{4}{|l|}{ Games } \\
\hline Mengunduh games & 13 orang & 15 orang & 3 orang \\
\hline Bermain games & 15 orang & 11 orang & 5 orang \\
\hline $\begin{array}{l}\text { Bermain games dgn komunitas games } \\
\text { online }\end{array}$ & 3 orang & 11 orang & 17 orang \\
\hline \multicolumn{4}{|l|}{ News } \\
\hline Membaca berita & 8 orang & 19 orang & 4 orang \\
\hline Mengunduh aplikasi berita & 6 orang & 17 orang & 8 orang \\
\hline
\end{tabular}

Dari 31 orang tersebut menjawab bahwa bentuk ketidakdisiplinan akibat Smartphone yaitu lalai dalam mengerjakan tugas, menggunakan Smartphone dalam jam PBM baik untuk chatting hingga men-download, lebih banyak menggunakan Smartphone dari pada belajar, dan lupa waktu hingga terlambat datang ke sekolah karena kurang tidur disebabkan malam menggunakan Smartphone. Hal ini juga terlihat dari hasil belajar mata pelajaran sosiologi kelas X pada Ulangan Harian 1 (satu) semester genap ditemukan hasilnya banyak yang tidak memenuhi batas KKM yaitu: 70, dari 36 siswa yang memenuhi KKM hanya 14 orang selebihnya 22 orang tidak melewati batas KKM tersebut. Penggunaan Smartphone yang berlebihan hingga tidak terkontrol memiliki banyak pengaruh pada aktifitas sehari-hari, salah satunya adalah terganggunya disiplin belajar.

Pada saat ini pengguna Smartphone di indonesia terus mengalami peningkatan. Penggunaan Smartphone mulai mendapatkan pengaruh terhadap perilaku komunikasi individu, dan Smartphone sudah menjadi sebuah kebutuhan bagi individu (Sharen, 2015). Melihat kegiatan siswa dalam menggunakan Smartphone, berbagai aturan mengharuskan pihak sekolah menindak dengan tegas ketika menggunakan Smartphone ketika pembelajaran berlangsung. (Asmurti, 2017) 


\section{Metode Penelitian}

Kelas X SMAN 2 Pariaman

Berdasarkan tujuan penelitian yaitu untuk mengetahui hubungan intensitas penggunaan Smartphone dengan disiplin belajar siswa kelas X SMA N 2 Pariaman. Maka jenis penelitian ini adalah penelitian ex-post facto yang bersifat korelasional. Teknik pengambilan sampel yang digunakan dalam penelitian ini proporsional random sampling, dari jumlah 354 siswa yang dijadikan sampel dalam penelitian ini adalah 78 siswa yang diambil secara acak.

\section{Uji Validitas}

Uji valid berarti instrumen tersebut dapat digunakan untuk mengukur apa yang hendak di ukur (Sugiyono, Metode Penelitian Bisnis), dalam uji validitas dapat digunakan rumus korelasi product moment. Menurut (Umar, 2002)

$$
\mathrm{r}_{\mathrm{xy}}=\frac{N \sum x y-(\Sigma x)(\Sigma y)}{\sqrt{\left[N \sum x^{2}-\left(\sum x\right)^{2}\right]\left[N \sum y^{2}-\left(\sum y\right)^{2}\right]}}
$$

nilai $r$ tabel dengan tingkat signifikansi $(\alpha)$ sebesar $5 \%$ dengan $n=30$ adalah 0,361 sehinga dalam penelitian ini instrumen dikatakan valid apabila $\mathrm{r}$ hitung $>0,361$

\section{Uji Reliabilitas}

Dalam pengambilan keputusan reliabititas, suatu instrumen dikatakan reliabel jika nilai Cronbach Alpha lebih besar dari 0,6.

Rumus untuk menghitung koefisien reliabiltas instrument dengan menggunakan Cronbach Alpha adalah sebagai berikut:

$$
r_{11}=\left(\frac{k}{k-1}\right)\left(1-\frac{\sum_{\sigma^{2}}}{\sigma_{t}^{2}}\right)
$$

Ket :

$r_{11}=$ reliabilitas instrument

$\mathrm{k}=$ banyak nya butir pertanyaan atau banyaknya soal

$\Sigma_{\sigma} 2_{=}$jumlah varian butir

$\sigma_{t}^{2}=$ varian total

\section{Teknik Analisis Data}

\section{Analisis deskriptif}

Analisis ini digunakan untuk menggambarkan masing-masing variabel secara mandiri yaitu intensitas penggunaan Smartphone (X) dan disiplin belajar (Y). Untuk mencari presentase jawaban angket dari responden, data yang diperoleh akan dicek dan diklasifikasi berasarkan nilai yang ditentukan yaitu skor tertinggi, skor terendah, rata - rata skor (mean), skor tengah (median), skor yang banyak muncul (modus) dan standar deviansi.

\section{Uji Normalitas}

Uji normalitas kolmogorov merupakan bagian dari uji asumsi klasik. Uji normalitas bertujuan untuk mengetahui apakah nilai residual berdistribusi normal atau tidak. Modal regresi yang baik adalah memiliki nilai residual yang berdistribusi normal. Dasar pengambilan keputusan, yaitu:

1. Jika nilai signifikansi $>0,05$, maka nilai residual berdistribusi normal

2. Jika nilai signifikansi $<0,05$, maka nilai residual tidak berdistribusi normal 


\section{Uji Hipotesis}

Kelas X SMAN 2 Pariaman

Analisis hipotesis ini yaitu melakukan analisis koefisien korelasi. Pengolahan data yang dilakukan untuk mencari harga koefisien korelasi adalah menggunakan rumus korelasi Product Moment yang dikemungka kan oleh Arikunto, yaitu :

$$
\mathrm{r}_{\mathrm{xy}}=\frac{N \sum x y-\left(\sum x\right)\left(\sum y\right)}{\sqrt{\left[N \sum x^{2}-\left(\sum x\right)^{2}\right]\left[N \sum y^{2}-\left(\sum y\right)^{2}\right]}}
$$

\section{Hasil dan Pembahasan}

\section{Analisis deskriptif}

Intensitas Penggunaan Smartphone

Data variabel intensitas penggunaan smartphone dikumpulkan melalui angket yang terdiri dari 56 butir item pernyataan dengan alternatif jawaban selalu (SL), sering (SR), kadang kadang (KD), Jarang (JR),dan Tidak pernah (TP) dengan skala 1-5 yang terdiri dari 8 indikator. Selanjutnya angket diberikan kepada responden untuk diisi. Dekripsi data variabel intensitas penggunaan smartphone dapat dilihat dari tabel berikut :

\section{Tabel 2. Deskripsi Data Intensitas Penggunaan Smartphone}

\begin{tabular}{cc}
\hline & $\begin{array}{c}\text { Intensitas Penggunaan } \\
\text { Smartphone }\end{array}$ \\
\hline $\mathrm{N}$ & 78 \\
\hline Mean & 1,54 \\
\hline Median & 1,62 \\
\hline Mode & 205,3 \\
\hline $\begin{array}{c}\text { Std. } \\
\text { Deviation }\end{array}$ & 14,3 \\
\hline Range & 72 \\
\hline Minimum & 123 \\
\hline Maximum & 195 \\
\hline Sum & 1,21 \\
\hline
\end{tabular}

Tabel 3. Hasil Analisis Per Indikator Intensitas Penggunaan Smartphone

\begin{tabular}{|c|c|c|c|c|}
\hline No. & Indikator & $\mathbf{N}$ & Persentase & Keterangan \\
\hline 1. & $\begin{array}{l}\text { Berlebihan dalam penguunaan } \\
\text { smartphone (durasi, isi, biaya) }\end{array}$ & 78 & $56,4 \%$ & Tinggi \\
\hline 2. & $\begin{array}{lll}\begin{array}{l}\text { Peningkatan dratis dari } \\
\text { penggunaan smartphone }\end{array} & \text { waktu } \\
\end{array}$ & 78 & $43,6 \%$ & Tinggi \\
\hline 3. & $\begin{array}{lrr}\text { Tidak mampu untuk } & \text { menghentikan } \\
\text { atau menurunkan } & \text { intensitas } \\
\text { penggunaan smartphone } & \end{array}$ & 78 & $46,2 \%$ & Sedang \\
\hline 4. & $\begin{array}{l}\text { Merasa gelisah ketika berhenti } \\
\text { menggunakan smartphone }\end{array}$ & 78 & $28,2 \%$ & Tinggi \\
\hline 5. & $\begin{array}{l}\text { Menggunakan smartphone lebih lama } \\
\text { dari yang diharapkan }\end{array}$ & 78 & $37,2 \%$ & Tinggi \\
\hline 6. & $\begin{array}{l}\text { Kehilangan hubungan antar pribadi } \\
\text { karena kebutuhan berlebihan dengan } \\
\text { smartphone }\end{array}$ & 78 & $33,3 \%$ & Tinggi \\
\hline 7. & $\begin{array}{l}\text { Berbohong terhadap orang - orang } \\
\text { terdekat }\end{array}$ & 78 & $100,0 \%$ & Sangat Tinggi \\
\hline
\end{tabular}


Hanifa Septiani, Ike Sylvia Hubungan Intensitas Penggunaan Smartphone dengan Disiplin Belajar Siswa Kelas X SMAN 2 Pariaman

8. Menggunakan Smartphone untuk lari 78 dari frustasi

$66,7 \%$

Sangat tinggi

Sumber: Pengolahan Data Primer 2019

Berdasarkan perhitungan dari 8 item indikator intensitas penggunaan smartphone, diketahui bahwa indikator yang paling dominan yaitu pada indikator ke 7 yaitu berbohong terhadap orangorang terdekat sebesar $100,0 \%$ sangat tinggi. Dan indikator ke 8 yaitu menggunakan smartphone untuk lari dari frustasi sebesar $66,7 \%$. Hal ini berarti ketika siswa menggunakan smartphone diwaktu belajar, secara diam-diam tanpa sepengetahuan guru yang mengajar termasuk pada indikator berbohong dengan orang ter dekat, dan juga pada indikator 8 berarti saat menggunakan smartphone siswa sudah mulai jenuh dengan pembelajaran yang berlangsung dikelas karna guru hanya terfokus kepada buku, dimana kedisiplinan dalan belajar terganggu karna hal itu.

Selain itu, indikator yang paling minimum terdapat pada indikator nomor 4 yaitu merasa gelisah ketika berhenti menggunakan smartphone $28,2 \%$. hal ini dapat diartikan bahwa sebesar $28,2 \%$ siswa merasa gelisah ketika berhenti menggunakan smartphone saat pelajaran berlangsung. sedangkan pada indikator 4 yaitu: tidak mampu untuk menghentikan atau menurunkan intensitas penggunaan smartphone sebesar $46,2 \%$ tergolong sedang.

Sedangkan pada indikator berlebihan dalam penggunaan smartphone (durasi, isi, biaya) tergolong tinggi dengan persentase $56,4 \%$, indikator peningkatan dratis dari waktu penggunaan smartphone tergolong tinggi dengan presentase 43,6\%, indikator menggunakan smartphone lebih lama dari yang diharapkan tergolong tinggi dengan presentase $37,2 \%$, indikator kehilangan hubungan antar pribadi karena kebutuhan berlebihan dengan smartphone dgn persentase 33,3\% tergolong tinggi.

Untuk lebih jelasnya tentang penjelasan diatas disajikan juga dalam bentuk Histogram, sebagai berikut :

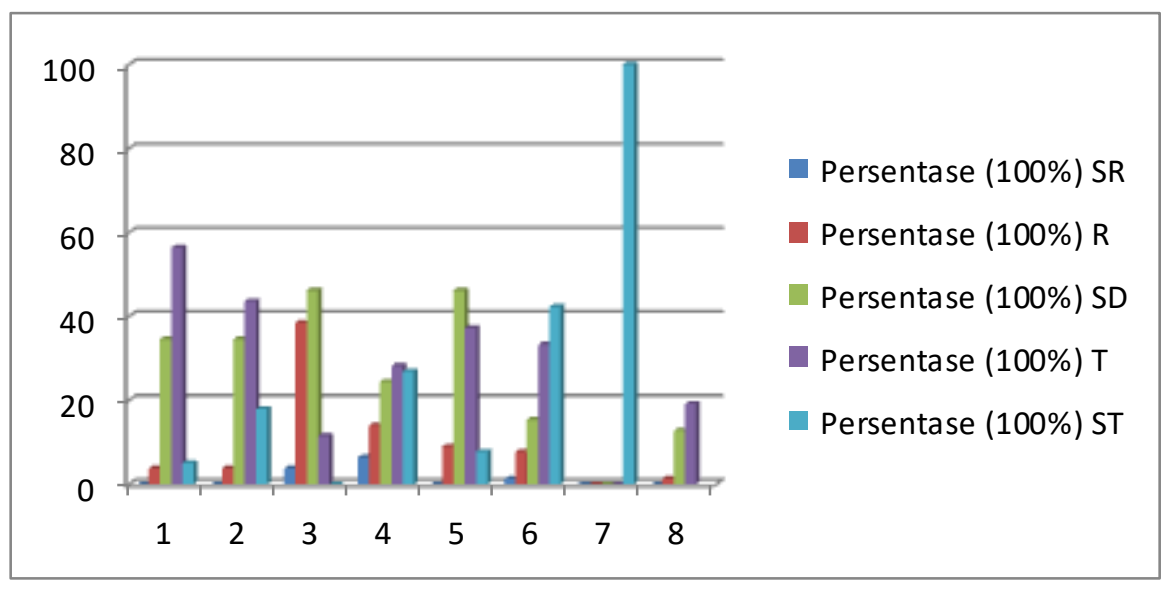

Gambar 1. Intensitas Penggunaan Smartphone

\section{Disiplin Belajar}

Data variabel disiplin belajar dikumpulkan melalui angket yang terdiri dari 30 butir item pernyataan dengan alternatif jawaban selalu (SL), sering (SR), kadang - kadang (KD), Jarang (JR),dan Tidak pernah (TP) dengan skala 1-5 yang terdiri dari 7 indikator. Selanjutnya angket diberikan kepada responden untuk diisi. Dekripsi data variabel intensitas penggunaan Smartphone dapat dilihat dari tabel berikut : 
Tabel 4. Deskripsi Data Disiplin Belajar

\begin{tabular}{lc}
\hline & Disiplin belajar \\
\hline $\mathrm{N}$ & 78 \\
\hline Mean & 1,10 \\
\hline Median & 1,16 \\
\hline Mode & 215,9 \\
\hline Std. Deviation & 14,6 \\
\hline Range & 71 \\
\hline Minimum & 72 \\
\hline Maximum & 143 \\
\hline Sum & 8645 \\
\hline
\end{tabular}

Tabel 5. Hasil Analisis Per Indikator Disiplin Belajar

\begin{tabular}{|c|c|c|c|c|}
\hline No. & Indikator & $\mathbf{N}$ & Persentase & Keterangan \\
\hline 1. & $\begin{array}{l}\text { Mengarahkan energi untuk } \\
\text { belajar secara kontinu. }\end{array}$ & 78 & $52,6 \%$ & Sedang \\
\hline 2. & $\begin{array}{l}\text { Melakukan belajar dengan } \\
\text { kesungguhan dan tidak } \\
\text { membiarkan waktu luang. }\end{array}$ & 78 & $43,6 \%$ & Sedang \\
\hline 3. & $\begin{array}{l}\text { Patuh terhadap rambu- } \\
\text { rambu yang diberikan guru } \\
\text { dalam belajar. }\end{array}$ & 78 & $32,1 \%$ & Tinggi \\
\hline 4. & $\begin{array}{l}\text { Patuh dan taat terhadap } \\
\text { tata tertib belajar di sekolah. }\end{array}$ & 78 & $76,9 \%$ & Sangat tinggi \\
\hline 5. & $\begin{array}{l}\text { Menunjukkan sikap } \\
\text { antusias dalam belajar. }\end{array}$ & 78 & $30,8 \%$ & Sangat tinggi \\
\hline 6. & 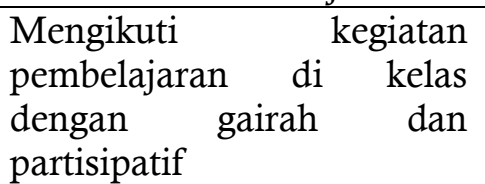 & 78 & $50,0 \%$ & Tinggi \\
\hline 7. & $\begin{array}{l}\text { Menyelesaikan tugas-tugas } \\
\text { yang diberikan guru dengan } \\
\text { baik. }\end{array}$ & 78 & $37,2 \%$ & Sedang \\
\hline
\end{tabular}

Sumber: Pengolahan Data Primer 2013

Berdasarkan hasil penelitian, disiplin belajar siswa kelas X SMA 2 Pariaman, sebagaimana diurai kan berdasarkan indikator berikut, indikator Mengarahkan energi untuk belajar secara kontinu tergolong sedang dengan persentase 52,6\%, Indikator Melakukan belajar dengan kesungguhan dan tidak membiarkan waktu luang tergolong sedang dengan persentase $43,6 \%$, indikator Patuh terhadap rambu-rambu yang diberikan guru dalam belajar tergolong tinggi dengan persentase $32,1 \%$, indikator Patuh dan taat terhadap tata tertib belajar di sekolah dengan persentasi tergolong sangat tinggi 76,9\%, indikator Menunjukkan sikap antusias dalam belajar tergolong tinggi 30,8\%, indikator Mengikuti kegiatan pembelajaran di kelas dengan gairah dan partisipatif tergolong tinggi dengan persentase 50,0\%, indikator Menyelesaikan tugas-tugas yang diberikan guru dengan baik tergolong sedangan dengan pesentase $37,2 \%$.

Untuk lebih jelasnya tentang penjelasan diatas disajikan juga dalam bentuk Histogram, sebagai berikut : 


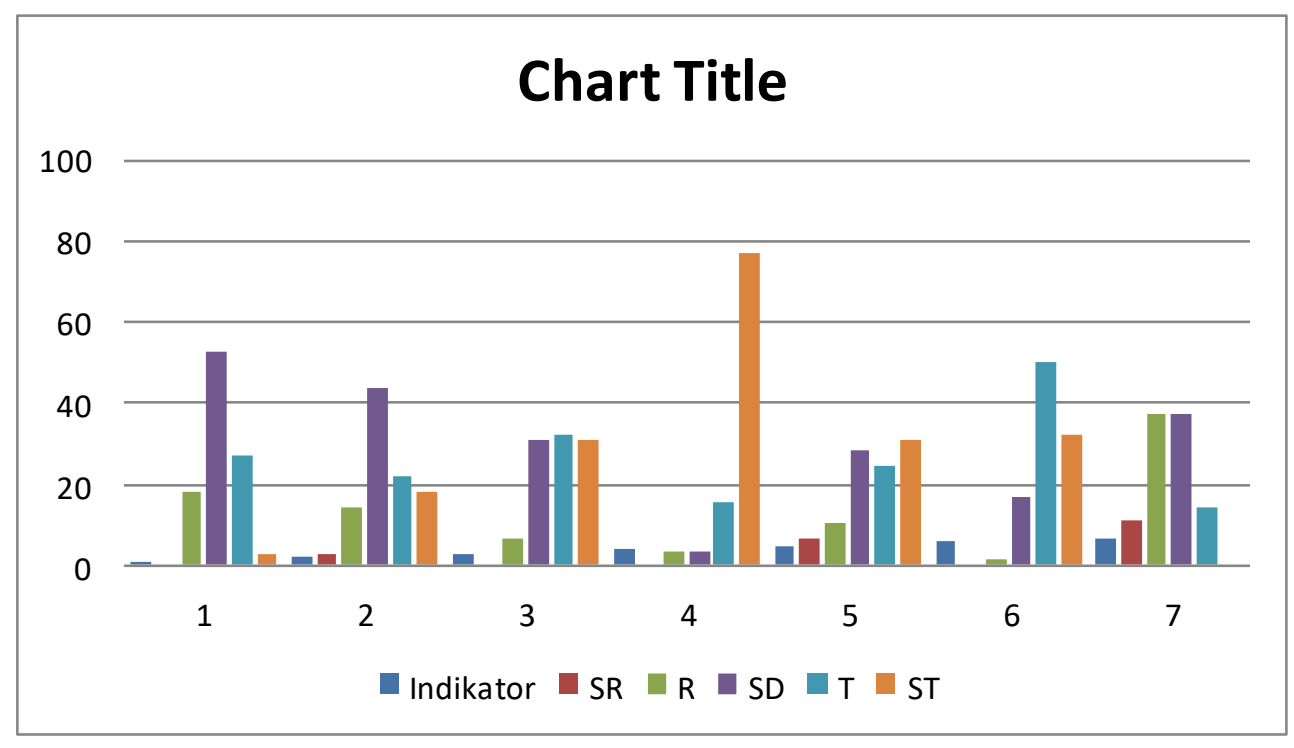

Gambar 2. Disiplin Belajar

\section{Uji Normalitas}

Sebelum melakukan uji hipotesis dengan menggunakan analisis korelasi Product moment, terlebih dahulu dilakukan uji persyaratan yaitu uji normalitas. Pengujian normalitas data dimaksudkan untuk menguji asumsi bahwa data berdistribusi normal. Uji normalitas dilakukan dengan pengolahan program SPSS menggunakan rumus One-Sample Kolmogorov-Smirnov Test.

Uji normalitas kolmogorov merupakan bagian daru uji asumsi klasik. Uji normalitas bertujuan untuk mengetahui apakah nilai residual berdistribusi normal atau tidak. Modal regresi yang baik adalah memiliki nilai residual yang berdistribusi normal. Dasar pengambilan keputusan, yaitu :

- Jika nilai signifikansi $>0,05$, maka nilai residual berdistribusi normal

- Jika nilai signifikansi $<0,05$ maka nilai residual tidak berdistrubusi normal

Hasil perhitungan uji normalitas dapat dilihat pada tabel dibawah ini :

Tabel 6. Hasil uji normalitas

\begin{tabular}{|c|c|c|}
\hline \multicolumn{3}{|c|}{ One-Sample Kolmogorov-Smirnov Test } \\
\hline \multicolumn{3}{|c|}{ Unstandardized Residual } \\
\hline $\mathrm{N}$ & & 78 \\
\hline \multirow{2}{*}{$\begin{array}{l}\text { Normal } \\
\text { Parameters }^{\mathrm{a}}\end{array}$} & Mean & .0000000 \\
\hline & Std. Deviation & 11.96355445 \\
\hline \multirow{3}{*}{$\begin{array}{l}\text { Most Extreme } \\
\text { Differences }\end{array}$} & Absolute & .102 \\
\hline & Positive & .065 \\
\hline & Negative & -.102 \\
\hline \multicolumn{2}{|c|}{ Kolmogorov-Smirnov Z } & .903 \\
\hline \multicolumn{2}{|c|}{ Asymp. Sig. (2-tailed) } & .388 \\
\hline a. Test distribut & is Nor & \\
\hline
\end{tabular}

Berdasarkan hasil uji normalitas diketahui nilai signifikansi 0,388 $>0,05$, maka dapat disimpulkan bahwa nilai residual berdistribusi normal. 


\section{Uji hipotesis}

Berdasarkan uji hipotesis yang dilakukan dengan menggunakan rumus korelasi ProductMoment, ternyata intensitas penggunaan smartphone memiliki hubungan dengan disiplin belajar siswa kelas $\mathrm{X}$ di SMA N 2 Pariaman, dengan perbandingan harga $\mathrm{r}$ yaitu $\mathrm{r}_{\text {hitung }}>\mathrm{r}_{\text {tabel }}$ dimana $r_{\text {hitung }} 0,484$ sedangkan nilai $\mathrm{r}_{\text {tabel }} 1,990$. Dengan demikian hipotesis $\mathrm{H}_{0}$ ditolak sedangkan $\mathrm{H}_{1}$ yang menyatakan hubungan antara intensitas penggunaan smartphone dengan disiplin belajar diterima. Dengan demikian dapat disimpulkan bahwa terdapat hubungan antara intensitas penggunaan smartphone dengan disiplin belajar siswa kelas X SMAN 2 Pariaman. Hasil analisis hipotesis ini terangkum pada tabel dibawah ini :

Tabel 7. Hasil Uji Hipotesis

\begin{tabular}{c|c|c|c|c|c|c|c}
\hline Korelasi & $\mathbf{N}$ & $\mathbf{R}$ & $\mathbf{R}^{2}$ & $\mathbf{r}_{\text {hitung }}$ & $\mathbf{r}_{\text {tabel }}$ & Sig & Ket \\
\hline $\mathrm{r}_{\mathrm{xy}}$ & 78 & 0,484 & 0,234 & 0,484 & 1,990 & 0,05 & Signifikan \\
\hline
\end{tabular}

Tabel menunjukkan koefisien korelasi antara hubungan hubungan antara intensitas penggunaan smartphone $(\mathrm{X})$ dengan disiplin belajar $(\mathrm{Y})$ sebesar 0,484 dan koefisien determinasi sebesar $(0,484)$ yaitu 0,234 dengan signifikan sebesar $5 \%$. Berdasarkan pengambilan keputusan ini maka $\mathrm{H}_{0}$ ditolak dan $\mathrm{H}_{1}$ diterima

Selanjtnya addalah menginterpretasikan koefisien korelasi hubungan antara intensitas penggunaan smartphone dengan disiplin belajar, sebagaimana Arikunto memberikan pedoman interpretasi koefisien korelasi yaitu: maka dapat diartikan bahwa hubungan antara intensitas penggunaan smartphone dengan disiplin belajar dapat di interprestasikan dalam kategori agak rendah karena korelasi variabel menunjukkan angka 0,484. Sebagaimana diketahui arikunti mengungkapkan bahwan interpretasi yang berkisar antara 0,400 sampai dengan 0,600 berada dalam kategori agak rendah, sehingga dapat dikatakan bahwa tingkat hubungan antara intensitas penggunaan smartphone dengan disiplin belajar siswa berada pada kategori agak rendah. Lebih lanjut dari olahan data didapat koefisien korelasi sebesar 0,484 dan $\mathrm{R}^{2}$ sebesar 0,234 yaitu 23,4\%. Hasil temuan ini dapat dikatakan bahwa variabel intensitas penggunaan smartphone mempunyai pengaruh terhadap disiplin belajar sebesar $23,4 \%$, sedangkan disiplin belajar lainnya dipengaruhi oleh faktor - faktor lain diluar faktor intensitas penggunaan smartphone sebesar 76,6\% yang tidak diteliti dalam penelitian ini. Jadi, intensitas penggunaan Smartphone signifikan dalam mempengaruhi disiplin belajar siswa.

\section{Penutup}

Hasil temuan ini dapat dikatakan bahwa variabel intensitas penggunaan Smartphone mempunyai pengaruh terhadap disiplin belajar sebesar $23,4 \%$, sedangkan disiplin belajar lainnya dipengaruhi oleh faktor - faktor lain diluar faktor intensitas penggunaan Smartphone sebesar 76,6\% yang tidak diteliti dalam penelitian ini. Jadi, intensitas penggunaan Smartphone signifikan dalam mempengaruhi disiplin belajar siswa.

\section{Daftar Pustaka}

Arga Lacopa Arisana, Pengaruh Kedisiplinan Siswa Dan Persepsi Siswa Tentang Kualitas Mengajar Guru Terhadap Prestasi Belajar Akuntansi Siswa Kelas Xi Ips Man Yogyakarta Ii Tahun Ajaran 2011/2012. (2012). Jurnal Pendidikan Akuntansi Indonesia, 23.

Arisana, A. L. (2012). Pengaruh Kedisiplinan Siswa Dan Persepsi Siswa Tentang Kualitas Mengajar Guru Terhadap Prestasi Belajar Akuntansi Siswa Kelas Xi Ips Man Yogyakarta Ii Tahun Ajaran 2011/2012, 2012. Jurnal Pendidikan Akuntansi Indonesia, 23.

Asmurti, A. A. (2017). Dampak Penggunaan Smartphone Dilingkungan Sekolah Terhadap Prestasi Belajar Siswa. Jurnal Komunikasi Kareba, 226.

Cheryl, A. J. (2005). Disiplin Positif. Jakarta: Prestasi Pustakaraya. 
Imron, A. (2011). Manajemen Peserta Didik Berbasis Sekolah. Jakarta: Bumi Aksara.

Muhammad Khafid, S. (2017). Pengaruh Disiplin Belajar Dan Lingkungan Keluarga Terhadap Hasil Belajar Ekonomi. Jurnal Pendidikan Ekonomi, 186.

Sharen Gifary dan Iis Kurnia N..(2015). Intensitas Penggunaan Smartphone Terhadap Perilaku Komunikasi . Jurnal Sosioteknologi , 2.

Nurul Amalia, Z. R. (2016). Hubungan Kedisiplinan Belajar Dan Motivasi Belajar Dengan Prestasi Belajar Sosiologi Siswa Kelas Xi Ips Man Purworejo . 3.

Rian Ayu Anggreani, S. K. (2015). Pengaruh Disiplin Belajar Dan Lingkungan Keluarga Terhadap Prestasi Belajar Mata Pelajaran Pengantar Akuntansi Dan Keuangan Siswa Kelas X Akuntansi Smk Palebon Semarang Tahun Ajaran 2014/2015 . Economic Education Analysis Journal , 428.

Sugiyono. (Metode Penelitian Bisnis). 2007. Bandung: Cv Alfabeta.

Sulistiyowati, S. (2001). Cara Belajar Yang Efektif Dan Efisien. Pekalongan : Cinta Ilmu.

Sylvia, I. (2012). HUBUNGAN ANTARA KONFORMITAS KELOMPOK TEMAN SEBAYA DENGAN DISIPLIN SISWA SMA NEGERI 5 PADANG. Diakronika, Vol XII, No 1 Th 2012, XII(1), 205-213. https://doi.org/10.31227/osf.io/tm5ba

Umar, H. (2002). Metode Riset Bisnis. Jakarta: Pt Gramedia Pustaka Utama.

Yosi Tri Agustin, Y. E. (2017). Hubungan Motivasi Belajar Dan Disiplin Belajar Siswa Kelas Ix Pada Pembelajaran Matematika Di Suatu Sekolah Kristen [The Relationship Between Learning Motivation And Learning Discipline Of Students Grade Ix In Mathematics Learning At A Christian School] . Journal Of Holistic Mathematics Education, 34.

Zainidar Aslianda, I. N. (2017). Hubungan Disiplin Belajar Terhadap Hasil Belajar Siswa Kelas Iv Sekolah Dasar Negeri 18 Banda Aceh. Jurnal Ilmiah Pendidikan Guru Sekolah Dasar , 2. 